\title{
Gender and EFL Student Teachers' Self-Efficacy
}

\author{
Fitri Budi Suryani ${ }^{1}$, Rismiyanto ${ }^{2}$ \\ Universitas Muria Kudus, Gondang Manis Bae Kudus \\ \{fitri.budi@umk.ac.id ${ }^{1}$,rismiyanto@umk.ac.id²
}

\begin{abstract}
Teachers' self-efficacy plays a significant role in determining the success or failure of teaching. The higher teachers' self-efficacy, the more successful the outcome of their teaching. Some studies reveal that teachers with high self-efficacy produce better students. Furthermore, they feel more satisfied with their jobs of teaching. However, few studies on self-efficacy are conducted with EFL student teachers. In fact, EFL student teachers will be EFL teachers in the future whose self-efficacy will lead them to be what kind of teachers they will be. This study aims at exploring the effects of gender on the self-effficacy of the EFL student teachers at the English Education Department of Universitas Muria Kudus. The participants of the study were the fifth-semester EFL student teachers. The instrument to collect the data is Teachers' Sense of Efficacy Scale developed by Tschannen-Moran and Woolfolk (2001). The result indicates that gender does not influence self-efficacy of EFL student teachers.
\end{abstract}

Keywords: self-efficacy, EFL student teacher, gender

\section{INTRODUCTION}

Teachers' self-efficacy can be defined as teachers' beliefs on their ability of teaching and motivating students. Bandura (1977)[1] defined self-efficacy as the "belief in one's capabilities to organize and execute the courses of action required to produce given attainments" (p. 3). As the concept of self-efficacy is applied to the teaching profession and the teacher's role in the classroom, self-efficacy is defined as the belief that one's capabilities can bring about desirable changes in students' behaviors and achievement (Gibson \& Dembo, 1984)[2]. Meanwhile, Tschannen-Moran, Woolfolk, and Hoy $(1998$, p. 233)[3] defined teacher efficacy as, "the teacher's belief in his or her capability to organize and execute courses of action required to successfully accomplish a specific teaching task in a particular context".

Teachers' self-efficacy plays a significant role in determining the succes or failure of teaching learning process. Pandergast, Gavis, and Keogh $(2011)^{[4]}$ note that in the context of education, teacher self-efficacy is considered a powerful influence on teachers' overall effectiveness with students.

Some studies (Ross, 1992 ${ }^{[5]}$; Fives \& Buehl, 2012 ${ }^{[6]}$ ) reveal the relationship between selfefficacy and quality of teaching in which the higher the self-efficacy, the better the quality of teaching. It was found out that teachers with high self-efficacy tend to use various strategis in teaching and implement student-centered learning (Pitkaniemi, 2017) ${ }^{[7]}$. High self-efficacy teachers are also able to give better support to their students and create more positive atmosphere in the classroom (Guo, Connor, Yang, Roehrig, and Morrison, 2012) ${ }^{[8]}$. Good and Brophy $(2003)^{[9]}$ state that high self-efficay teachers maintain student participation level at higher levels 
that can be seen from their spending more time keeping track of their students, supervising their work during lesson, and providing them with group work and collaborative task. Furthermore, self-efficacy also brings impact on job satisfaction. Carpapra, Borgonelli, Borgoni, and Steca (2003) ${ }^{[10]}$ mention that teachers who have high self-efficacy admit that they feel more satisfied with their job of teaching

The studies of self-efficacy in student teachers also indicate similar results. Kula and Tasdemir (2014) ${ }^{[11]}$ explain that students' self-efficacy contribute directly to their academic success, peer acceptance and reducing depression and problem behaviour that can undermine productive engagement in academic pursuits. Furthermore, Pandergast, Garvis, and Keogh (2011) highlight that if student teachers develop greater beliefs about their self-efficacy, it seems logical to expect that they may be more likely to stay in the profession after five years. This means their self-effcacy will lead them to what kind of teachers they will be.

Pandergast, Garvis, and Keogh (2011) explain that teacher self-efficacy is influenced by four sources. They are the mastery experiences (serving as an indicator of capability), verbal persuasion (verbal influences on your perceived capability), vicarious experiences (modelling and observation of techniques), and emotional arousal (associated with the perceived capability that influence the process and outcomes of the task attempted).

The four sources undergo a form of cognitive processing that determines how the source of information will be weighted and influence the desired teaching task. Mastery experiences are considered the most powerful influence as they provide authentic evidence of teacher's performance in a teaching situation. Successful performance by a teacher leads to increased selfefficacy, while a failure creates a decrease in self-efficacy. As teachers develop mastery experience that lead to accumulating increases in teacher self-efficacy, they rely on these as memories and interpretations of similar past teaching experiences (Tschannen-Moran, Woolfolk Hoy \& Hoy, 1998). This is in line with Pitkaniemi (2017) who states that teachers' self-efficacy may change due to teachers work experience.

The other factor like gender is also found out to affect self-efficacy. Riggs (1991) [12] explains that gender affects elementary science teacher. Britner and Pajares (2001) ${ }^{[13]}$ also indicate that girls perfomed stronger science self-efficacy than boys. Furthermore, Huang (2013) ${ }^{[14]}$ reveals the same result that gender differences exist in language arts, mathematics, computer, and social self-efficacy.

However, those studies researched either student and teachers and mostly in the fields of science. None of the studies were conducted in the field of Englis as a Foreign Language (EFL) with student teachers. Therefore, this study intends to investigate the effect of gender on selfefficacy of the EFL student teachers.

\section{METHODOLOGY}

This study aims at exploring the effects of gender on the self-effficacy of the EFL student teachers. The design of the study is quantitative. It seeks whether female EFL student teachers differ from male EFL student teachers on self-efficacy.

The participants of the research were the fifth semester student teachers at the English Education Department of Universitas Muria Kudus. They were selected as they can provide the adequate data for this research. The EFL student teachers at the Englis Education Department of Universitas Muria Kudus take four years to complete their study and graduate from the department. This department offers a teacher education program for EFL student 
teachers who want to become English teachers. The program provides EFL student teachers with theoretical as well as practical courses.

The theoretical courses are given in the forms of content knowledge and pedagogical knowledge. The content knowledge provides the subject matter of English content which is usually taken by EFL student teachers in the beginning year of their study (first year). Meanwhile, the pedagogical courses provide EFL student teachers with strong theoretical teaching background that familiarize EFL student teachers with the elements, theories, approaches, and methodologies for teaching English as a foreign language. Those courses are usually taken in the second year of their study. The practical courses include teaching practicum in Speaking for Instructional Purposes, microteaching course and teaching internship program. This series of teaching practice courses provides the link between the theories they have taken before and the practice. Thus, the EFL student teachers have teaching practice that offer them to gain insights and understanding as to how this profession of English teacher is about.

Those EFL student teachers have conducted teaching practice in the course of Speaking for Instructional Purposes. This teaching experience might cause them to reveal their self-efficacy. The number of the EFL student teachers as the participants $f$ this study is 64 consisting of 55 female EFL student teachers and 9 male EFL student teachers. The number of female EFL student teachers outstands that of males because of the fact that females tend to be more interested in being English teachers than males.

This study used questionnaire as the instrument to collect the data. It is adopted from the Teachers' Sense of Efficacy Scale developed by Tschannen-Moran and Woolfolk (2001). It consists of twenty-four questions grouping in three dimensions, namely student engagement, instructional strategies, and classroom management. To answer the questions, the EFL student teachers must choose from the five options presented following the Likert scale. The options range from (1) strongly agree, (2) agree, (3) neutral, to (4) disagree, and (5) strongly disagree. The questionnaire was given to the EFL student teachers in the end of the fifth semester when they have completed the course of Speaking for Instructional Purposes.

To analyse the questionnaire, both descriptive and inferential statistics were applied. Since the study intends to test the difference between two independent groups (female EFL student teachers and male EFL student teachers), it runs the test of the independent sample t-test. The gender difference is calculated in terms of each dimension of self-efficacy that consists of student engagement, instructional strategies, and classroom management.

\section{FINDING AND DISCUSSION}

To find out the effect of gender on the EFL student teachers' self-efficacy, the means of each dimension of self-efficacy (student engagement, instructional strategy, and classroom management) obtained from the questionnaire were submitted to an independent sample t- test as presented in Table 1 .

Table 1. The Result of independent sample t-test for self-efficacy

\begin{tabular}{l|c|c|c}
\hline \multicolumn{1}{c}{ Dimension of Self-efficacy } & $\mathbf{t}$ & $\mathbf{d f}$ & $\mathbf{P}$ \\
\hline Student engagement & -.799 & 62 & .427 \\
\hline Instructional strategies & -1.276 & 62 & .207 \\
\hline Classroom management & -.605 & 62 & .548 \\
\hline
\end{tabular}

Table 1 illustrates that the difference between the female EFL student teachers and the male student teachers in term of student engagement reached significant level t $(62)=-.799, \mathrm{p}>.05$. 
Thus, there is not any significant difference between the student engagement dimension of selfefficacy of the female EFL student teachers and that of the male EFL student teachers.

The result of the second dimension of self-efficacy, i.e. instructional strategies indicates that $\mathrm{t}(62)=-1.276, \mathrm{p}>.05$. Hence, the instrcutional strategies of the female EFL student teachers does not differ significantly from that of the male EFL student teachers.

The similar finding is also found for the classroom management dimension of self-efficacy. The $t$-test results $(t=-.605, p>.05)$ shows that there is no significant difference between the classroom management of the female EFL student teachers and that of the male EFL student teachers.

The results of this study reveal that the female EFL student teachers do not differ significantly from the male EFL student teachers regarding their self-efficacy for student engagement, instructional strategies, and classroom management. This breaks the assumption that females usually have higher motivation and beliefs dealing with teaching. In other words, they might show higher self-efficacy than males.

However, as this study shows, the gender of EFL student teachers does not contribute to their self-efficacy. This might imply that female and male EFL student teachers perceive their beliefs about teaching and motivating students quite the same. In term of student engagement, both female and male EFL student teachers have the same confidence that they can handle not only difficult students, but also problematic students who have academic and psychological problems like low confidence and interest. The general assumption held by many societies admits that females can do better when dealing with students' attitude and problems as females are mostly more patient than males. This assumption is denied in this study since the female EFL student teachers and male EFL student teachers perform similar beliefs when they engage with their students. In addition, the female EFL student teachers and male EFL student teachers hold the same beliefs that they are able to make their students to be more critical and creative and value learning. Therefore, both gender view themselves to have ability and skills to engage with students, solve the problems emerged with their students, and bring good impact to their students' academic life.

In term of instructional strategy, the female EFL student teachers and male EFL student teachers also do not display differences. They both believe that they master their material well so that they can answer their students' questions. Moreover, they perceive that they have the capability to implement the suitable teaching and learning methods and strategies that suit their level of students. This means that both female EFL student teachers and male EFL student teachers believe that they can teach and deliver the material well. Besides, they know what assessment strategies that do best for their class. Finally, the female EFL student teachers and the male EFL student teachers share similar view that they are able to set an interesting teaching circumstance that suits their various levels of students.

The third dimension of self-efficacy that reveals similar perceptions between the female EFL student teachers and the male EFL student teachers in this study is classroom management. It is usually defined as the teachers' efforts to keep the class organized and the students attentive, focused, and on task. Regarding classroom management, the female EFL student teachers perceive themselves the same as their male colleagues. They both believe that they can handle problems in the classroom like disruptive and defiant students. One of the ways is by establishing a good classroom management system. Both female EFL student teachers and male EFL student teachers have their confidence in this ability. Furthermore, they view themselves to possess such ability and skills to make their students follow the rules and keep the routines done. 
The result of this present study seems to contradict some of the previous studies. The studies by Riggs (1991), Huang (2013), and Britner and Pajares (2001) reveal that gender differences exist in self-efficacy. Nonetheless, their studies were conducted either with students or teachers. In addition, their scope of the study is mostly in science and none in EFL. To infer, the studies of gender differences might bring about distinct result due to the participants and field of the study.

\section{CONCLUSIONS}

Despite many differences found between females and males, they share similarities as well, one of which is self-efficacy. Female EFL student teachers perceive self-efficacy in terms of student engagement, instructional strategy, and classroom management, the same as their male colleagues. This indicates that gender differences do not appear in the beliefs in teaching and motivating students.

This result of study implies that both female and male EFL student teachers view themselves similarly as future English teachers who have the same passion, interest, and efforts in being successful English teachers. Furthermore, they have the same beliefs that they can engage with students well, create good teaching learning process, and manage the classroom successfully.

The pedagogical implication of this present study is intended for teacher educators. They are suggested to treat female EFL student teachers and male EFL student teachers equally. In addition, they should not follow the stereotypes held by most societies about the differences between the female and male EFL student teachers, such as the female EFL student teachers usually have better motivation and performance in teaching, and thus exceed their male EFL student teachers in terms of teaching thingy, inlcuding self-efficacy.

This study also had limitation that needs to be explored in further reserach. This current study made use of quantitative data only to seek the effect of gender on the EFL student teachers' self efficacy. Therefore, the direction for further research would be to have the qualitative data in order to explore more on the gender differences in EFL student teachers' self-efficacy. Such data can be collected through interview or EFL student teachers' selfreported journals.

\section{References}

[1] A. Bandura, "Self-efficacy: Toward a unifying theory of behavior change," Psychological Review, 84, pp. 191-215, 1977.

[2] S. Gibson \& M Dembo, "Teacher efficacy: A construct validation, " Journal of Educational Psychology, 76, 569-582, 1984.

[3] M. Tschannen-Moran., A. Woolfolk., \& W.K. Hoy, "Teacher efficacy: Its meaning and measure," Review of Educational Research, 68, 202-248, 1998.

[4] D. Pandergast., S. Garvis and J. Keogh, "Preservice Student Teacher Self-Efficacy Beliefs: An Insight into the Making of Teachers," Australian Journal of Teacher Education. 36(12), 46-58.

[5] J.A. Ross, "Teacher efficacy and the effects of coaching on student achievement," Canadian Journal of Education, vol. 17, No. 1, pp. 51-65. 1992.

[6] H. Fives \& M. Buehl, "Spring cleaning for the "messy" construct of teachers' beliefs: What are they? Which have been examined? What can they tell us?" In K. R. Harris, S. Graham, \& T. Urdan (Eds.), APA educational psychology handbook: Volume 2.Individual 
differences and cultural and contextual factors (pp. 471-499). Washington, DC: American Psychological Association., 2012.

[7] H. Pitkaniemi, "A teacher's practical theories, self-efficacy, and emotions, “ Nordisk Tidskrift for Allman Didaktik, Vol. 3, No.1, pp. 2-23, 2017.

[8] Y. Guo., C.M. Connor., Y. Yang., A.D.Roehrig \& F.J. Morrison, "The effects of teacher qualifications, teacher self-efficacy, and classroom practices on fifth graders' literacy outcomes,“"Elementary School Journal, Vol. 113, pp. 3-24, 2012.

[9] T.L.Good \& J.E. Brophy, " Looking in classrooms (9th ed.),“ Boston: Allyn and Bacon, 2003.

[10] G.V. Caprara., C. Barbaranelli., L. Borgogni, L \& P. Steca,“ Efficacy beliefs as determinants of teachers' job satisfaction, “ Journal of Educational Psychology, 95, pp. 821-832, 2003.

[11] S. Kula and M.Tasdemir, "Evaluation of preservice teachers' academic self-efficacy level in terms of some certan variables," Procedia Social And Behavioral Sciences. 141, pp.686690.

[12] I.M. Riggs, "Gender differences in elementary science teacher self-efficacy," in The Annual Meeting of the American Educational Research Association, 1991.

[13] S.L. Britner \& F. Pajares, "Self-efficacy beliefs, motivation, race, and gender in middle school science," Journal of Women and Minorities in Science and Engineering, vol. 7, no. 4, 2001.

[14] C. Huang, "Gender differences in academic self-efficacy: a meta-analysis," European Journal of Psychology of Education., vol. 28, no. 1, pp. 1-35, 2013. 